\title{
The Effect of Accessibility on Performance of Maternal and Child Health Policy Implementation in East Nusa Tenggara Province, Indonesia
}

\author{
Tat Florentianus ${ }^{1} \&$ Bait M. Maria ${ }^{2}$ \\ ${ }^{1}$ Nursing Department of Poltekkes Kemenkes Kupang, Liliba, Kupang, Indonesia \\ ${ }^{2}$ S.K Lerik Hospital of Kupang, Liliba, Kupang, Indonesia \\ Correspondence: Florentianus Tat, Jurusan Keperawatan Poltekkes Kemenkes Kupang, Jl. Piet A. Tallo, \\ Liliba-Kupang, Indonesia. Tel: 62-81-353-010-401. E-mail: florentianustat@yahoo.co.id
}

Received: July 29, 2019 Accepted: September 18, 2019 Online Published: September 30, 2019

doi:10.5539/gjhs.v11n11p180 URL: https://doi.org/10.5539/gjhs.v11n11p180

\begin{abstract}
Background: The fact shows that the performance of health service policy implementation from the output aspect (out put) and the outcome (out comes) policy has not been in line with expectations. This condition will also have a direct influence on the Human Development Index in East Nusa Tenggara Province, where the position of East Nusa Tenggara is still in the order of 32 out of 34 provinces in Indonesia, which ranges from 68.77. The main purpose of this study was to identify the health service accessibility in East Nusa Tenggara. Furthermore, this study also intended to find out the performance of policy implementation and was to identify the effect of accessibility of health sevices on the performance of policy implementation on mothers and children in East Nusa Tenggara.
\end{abstract}

Subject and Method: This research is a quantitative study, conducted in 11 districts, 104 community healths services, and has 235 health workers as respondents in East Nusa Tenggara Province of Indonesia.

Result: The results of the study on conditions of accessibility and networking in maternal and child health services in East Nusa Tenggara Province are still lacking (mean 2.7), meaning that conditions of accessibility in East Nusa Tenggara Province do not support the implementation of $\mathrm{MCH}$ policies. The performance of $\mathrm{MCH}$ policy implementation in East Nusa Tenggara Province is in the 3.36 category, meaning that the targets of MCH services that have been made have not been maximally realized. There is a correlation between accessibility conditions and the performance of $\mathrm{MCH}$ policy implementation $(\mathrm{p}=0.00)$, the correlation coefficient of 0.429 shows that this correlation is quite strong, although not very strong. This correlation shows a positive relationship which means that if the accessibility conditions are easier, it will improve the performance of $\mathrm{MCH}$ policy implementation. The effect of accessibility on policy performance has been carried out partial linear regression test ( $t$ test), found $t$ count $=19.0115>\mathrm{t}$ table 1.97 means that there is a significant influence on the condition of accessibility to the performance of $\mathrm{MCH}$ policies in East Nusa Tenggara Province.

Conclusion: Accessibility to health services in East Nusa Tenggara Province is still lacking, the policy implementation performance is good and there is a significant and positive influence between service accessibility and policy implementation performance.

Recomendation: The government is expected to be more serious in efforts to open the accessibility of health services and set more realistic targets that could be achieved.

Keywords: accessibility, performance of $\mathrm{MCH}$ Policy implementation

\section{Introduction}

The description of maternal health and in East Nusa Tenggara can be seen, among others, the percentage of achievement of delivery assistance in health facilities in 2014 was $86.9 \%$ and deliveries assisted by health workers were 86.63\%. The maternal mortality rate (MMR) in 2013 and 2014 was 179/100,000 live births) and 159 / 100,000 live births, this is still quite high when compared to the target of 153/100,000 live births). While for infant and toddler mortality rates reached 32/1000 live births and 40/1000 live births) still above the national value of 23/1000 live births) and 32/1000 KH. The above achievements are compared with the Millennium Development Goals (MDGs) in 2015, namely the mortality rate of 23/1000 live births), and deaths of 32/1000 live births infants, while the maternal mortality rate is 102 / 100,000 live births in 2015 and more than $90 \%$ of women giving birth are 
assisted by trained health personnel. Maternal and child health indicators still show the unsuccessful implementation of maternal and child health policies in East Nusa Tenggara. This condition will have a direct influence on the East Nusa Tenggara Human Development Index, in the order of 32 out of 34 provinces, which ranges from 68.77 .

The unsuccessful performance of the implementation of maternal and child health policies in East Nusa Tenggara is thought to be due to limited accessibility to health services. Wiku (2008) which states that the condition of Indonesia's accessibility which consists of islands with vast ocean areas is one of the inhibiting factors for the government in trying to improve the health status of the people located in remote areas, because to reach these areas requires means of transportation and communication with high operational costs, while the government has not been able to fulfill it (Wiku, 2008).

The maternal and child health policy aims to reduce MMR/IMR but has not achieved the level set by the government. The factor of accessibility of health services were thought to be a major influence. Therefore, the primary research question of this research is "how the accessibility of health services, the performance of policy implementation and the effect of the accessibility of health services on the performance of the implementation of maternal and child health policies in East Nusa Tenggara Province?"

The main purpose of this study was to identify the health service accessibility in East Nusa Tenggara. Furthermore, this study also intended to find out the performance of policy implementation and was to identify the effect of accessibility of health sevices on the performance of policy implementation on mothers and children in East Nusa Tenggara.

\section{Subject and Method}

This research uses quatitative method. Data collected using valid and reliable questionnaire. The questionnaire consist of demographic data, health services accessibility data and perfomarnce data on the implementation of maternal and child health policies in East Nusa Tenggara. Data collection was carried out in 11 districts of East Nusa Tenggara, 104 community health centers and 235 health workers, Data measurement uses a Likert scale and will be analyzed as univariate, bivariate and multivariate.

\section{Research's Result and Discussion}

\subsection{Accessibility to Health Services}

Accessibility is the affordability of the community to achieve adequate health facilities to obtain health services. These variables include the distance of health facilities to the place of residence of the community, the travel time needed and the means of transportation used to reach health facilities. An overview of this condition can be seen in the following table:

Table 1. Community accessibility in MCH Policy Implementation in East Nusa Tenggara Province in 2017

\begin{tabular}{ll}
\hline Indicators & Mean \\
\hline Distance & 2.7 \\
Reach target groups to health facilities (Distance of houses with health facilities) & 2.7 \\
The target location is reached by the policy implementer & 2.7 \\
All target groups have equal access to MCH policies. & 2.8 \\
Traveling time & 2.7 \\
Ease in travel time (travel time to health facilities) & 2.7 \\
How easy is the location of the MCH service & 2.7 \\
Length of time to reach the target & 2.7 \\
How long does it take to get health services in an adequate Local Government Clinic & 2.7 \\
Mean of transportation & 2.7 \\
Ease of getting transportation equipment (Availability of transportation equipment to reach health facilities) & 2.6 \\
The ease of finding a means of transportation & 2.6 \\
Ease of access roads to health facilities & 2.7 \\
Ease in finding / calling transportation equipment & 2.7 \\
Average variable value & 2.7 \\
\hline
\end{tabular}


The results of the study as contained in table 1. explain that the support of accessibility and networking variables is still lacking (mean 2.7), meaning that the conditions of accessibility in East Nusa Tenggara Province do not support the implementation of $\mathrm{MCH}$ policies. The distance of the people who are still very far away with health facilities. Long distances cause long travel times, because most people walk to health facilities because there are no public vehicles or the area does not yet have roads for public transportation. Many people take patients to health centers or health facilities using stretchers. Distant mileage causes the mother to be late to get health services and too late to get medical treatment or professional health personnel. Most pregnant women prefer to be helped by a traditional birth attendant or even be helped by her own husband. This will put the risk of maternal and child deaths getting bigger.

Physical access dimensions (including geographical problems), costs, and social access. Accessibility of health services is a consequence of the geographical conditions of East Nusa Tenggara Province as an archipelago with very extreme geographical regions.

The results of the study show that accessibility and networking in policy implementation are in the less category (mean value 2.7). The distance of the community is very far from health facilities, causing a long travel time, most people walk because there are no public transportation or there is no public access road. People sometimes take patients to health centers or health facilities using stretchers by foot.

This study is in line with Subarsono's (2013) submission that environmental factors influence the implementation of policies including geographical characteristics, natural resources, climate and topography, demographic variables such as the number and distribution of population, social structure and economic system.

According to Laksono (2016: 10), the disparity in accessibility of health services is allegedly directly proportional to the inequality of development described as a dichotomy of Java - Bali with Non Java - Bali, or the Western Region of Indonesia compared to Eastern Indonesia. Inequality does not only occur in the availability of health service facilities, tools and technology, but also in the availability of health workers in each region. The existence of basic health facilities according to the results of a survey, 2013 Basic Health Research (Riskesdas) showed a disparity of around $20.9 \%$. Greater disparity occurs in advanced health facilities. The number of households who knew the existence of a Government Hospital in Bali Province was $88.6 \%$, while the lowest position was East Nusa Tenggara Province at $39.6 \%$. Whereas related to the existence of a Private Hospital, the highest number of households claiming that there are Private Hospitals around their homes is in the Special Province of Yogyakarta (reaching 82.4\%), and the lowest number is in West Sulawesi Province (amounting to $15.1 \%$ ).

Efforts to facilitate accessibility of health services with Ambulance Local Government Clinic to pick up patients. The long distance to the Local Government Clinic causes the mother to be late to get health services or treatment by a doctor. This also causes mothers to prefer being helped by traditional birth attendants or even helped by their own husbands. The impact that arises is the increased risk of maternal and child mortality.

The results of the study explained that the performance of the policy implementation category was well aligned with the conditions of category accessibility quite easily and easily. But the performance of the policy category is not well aligned with the conditions of accessibility of the category is not good too. There is a correlation between accessibility variables with the performance of policy implementation $(p=0.00)$, the correlation coefficient of 0.429 shows that this correlation is quite strong, meaning that if it is easier to access it will improve the performance of policy implementation.

This is similar to the research of Yosef Leu Maing, et al (2013) which shows that accessibility difficulties, limited health human resources and financing are the main obstacles to policy implementation. The main problem with implementing referrals is transportation and financing. This research proves that the difficulty of the state of accessibility, limited health human resources and financing, has made implementing health service policies difficult.

The results of the above research are in line with the opinion of Wiku (2008) which states that the condition of Indonesia's accessibility which consists of islands with vast ocean areas is one of the inhibiting factors for the government in trying to improve the health status of people located in remote areas, due to reaching the area need transportation and communication facilities with high operational costs, while the government has not been able to fulfill them (Wiku, 2008).

According to Laksono (2016: 10), the availability of health service facilities is no different from the availability of health workers. The indicator of the level of accessibility of health services carried out by Jones is measured using several variables based on demand factors and supply factors. Demand factors include the number of visits to health service facilities, population, utilization of inpatient care, and utilization of emergency units. Supply factors 
include the number of general practitioners, number of specialist doctors, and number of service facilities.

Increasing accessibility and equity can be an acceleration step to achieve justice in the health system performance. Achieving equitable health services has a number of dimensions. Access to health services must be determined by actual demand for health services rather than just the ability to pay or geographical location.

Specific conditions like this certainly require adequate transportation equipment, especially for connecting islands. An ambulance is needed by the sea or maybe a floating health center that can provide health services to the community on the islands. Thus the community has equal access to other communities in obtaining health services.

People in need must have access to health services available within a reasonable period of time. Kiwanuka's research (Laksono, 2016: 10) in Uganda shows that poor people who are vulnerable to disease have lower access to health services than non-poor people.

Barriers to access arise from both service providers and consumers. Distance to health service facilities, perceived quality of care and availability of drugs are the main determinants of the use of health care facilities. Other obstacles that are also felt by the community are the lack of specialists in public facilities, direction, attitudes of health workers, maintenance costs, and lack of knowledge in the community.

Jones stated that access to health services can be influenced by three barriers, namely: (1) physical barriers (transportation, mobility); (2) economic barriers (ability to pay, ownership of health insurance). (3) geographical barriers (location or proximity to available health facilities).

Communities in East Nusa Tenggara Province may get the three types of obstacles mentioned above. Physical barriers are related to the limitations of transportation, both transportation equipment such as vehicles and transportation routes, namely roads. Economic barriers are also experienced by the people of East Nusa Tenggara Province, namely poverty and the inability to have health insurance or health insurance coverage, most health insurance is funded by the government.

According to Carrillo (Laksono (2016: 15) there are three (3) categories of obstacles, namely financial, structural, and cognitive barriers. These barriers are related to the screening process, availability of health services, and lack of facilities, which in turn results in poor disparity or health status .

Health services in disadvantaged areas, borders and islands, need to pay attention to the demands and needs of the local community and in accordance with the developments and problems faced. Efforts to improve health services need to consider geographical conditions, weather, availability of infrastructure, human resources, funding and capabilities of local governments and communities, so that there is an expected increase in the reach and quality of services to communities in the region (Ministry of Health, 2012).

\subsection{MCH Policy Performance}

The performance of the intended MCH service policy is how far the policy targets have been achieved in accordance with policy standards. This study uses a statement that shows the implementation of activities that describe the achievements that have been set.

Table 2. Average Value of Indicators for Achieving Performance in MCH Policy Implementation in East Nusa Tenggara Province in 2017

\begin{tabular}{lc}
\hline Indicators & (Mean) \\
\hline $\begin{array}{l}\text { Health services for pregnant, childbirth and postpartum mothers and infants from 0-28 days, normal and with } \\
\text { complications. }\end{array}$ & 3.8 \\
The Puskemas provides antenatal care at least 4 times. & 4.0 \\
Antenatal care is carried out by trained personnel in Obstetrics and Neonatal Emergency. & 3.7 \\
Childbirth assistance is carried out by midwives, general practitioners, midwifery specialists. & 3.8 \\
The Puskemas prioritizes prevention of infection, standardized delivery assistance, refers, implements IMD, & 3.8 \\
prevents complications. & 3.8 \\
Postpartum services at least 3 times (KF-1) 6 hours after delivery to 3 days, (KF-2) days 8 to 14 days after delivery. & 3.8 \\
(KF-3) day 36 to day 42 after delivery & 3.8 \\
Postpartum Services by nurses, Midwives, General Physicians, Obstetrics and Genekology Specialists. \\
Neonatal care uses a comprehensive approach, integrated management of young babies, zero hepatitis B
\end{tabular}


immunization, counseling.

Minimum neonatal services are 3 times $(\mathrm{KN}-1),(\mathrm{KN}-2),(\mathrm{KN}-3)$.

Obstetric services and complications of pregnant, maternity and postpartum

PONED Health Center is according to the standard.

The Puskemas has health workers who can provide midwifery and neonatal services and have been trained by PONED at least 3 people who live around the location of the Local Government Clinic, namely: a general practitioner, a midwife, a nurse.

There are at least tools and drugs, manuals and managerials, rooms for assisting childbirth, ventilation and lighting that are eligible, aseptic atmosphere, beds of at least 2 pieces, clean water available, bathrooms / wc available

Able to provide services for complications such as preeclampsia, eclampsia, bleeding, etc.

The person in charge of the PONED Local Government Clinic is a general practitioner

PONEK hospital according to standards.

Sources of funds for delivery assistance services and handling complications and referrals from the Government.

Allocation of funds for normal delivery costs at PONED Local Government Clinic and PONEK hospitals is determined by the regent's decision.

All labor costs are borne by the government or regional government and other non-binding budgets.

The cost of referral of pregnant women along with their health and family members going home is borne by the government or regional government and other non-binding budgets.

Prepared waiting house.

Complicated pregnant women are set 2 weeks before delivery to the waiting house and 1 week after delivery.

The cost of transporting blood donors is borne by the government.

The data in Table 2 shows that the average performance value of $\mathrm{MCH}$ policy implementation in East Nusa Tenggara Province is in the category of 3.36. This average value shows that MCH service targets have not been maximally realized. In general, the achievement of $\mathrm{MCH}$ policy performance in East Nusa Tenggara Province is in a fairly good category even though there are still many targets that have not been achieved, meaning that the policy has not been able to produce results in accordance with the expectations of the policy objectives themselves.

The performance of public policy can be interpreted as an evaluation of a policy. Performance values cannot be separated from the model, methods and standards or indicators. Policy efficiency can be done by comparing input and output policies. While the effectiveness of policies can be seen from the output, oucames and impact of a policy.

According to Anderson (Islamy, 2002: 116), the dimensions of impact in state policy are: (1) Impact of expected and unexpected policies on both the problem and the community; (2) Policy waste on the situation or people who are not the main goals / objectives of the policy; (3) Policy impacts can occur in the present or future conditions; (4) The impact of policy affects direct costs and indirect costs as experienced by community members.

The aspect of human resources (HR), namely the Puskemas which has health workers who can provide midwifery and neonatal services shows that the availability of health workers is not evenly distributed in all Local Government Clinic, meaning that there are Local Government Clinic that have doctors but there are also Local Government Clinic that do not have doctors.

Available equipment shows that not all Local Government Clinic have equipment standards in accordance with $\mathrm{MCH}$ policy expectations. Not all Local Government Clinic have waiting homes for pregnant women at risk. System aspects, including SOPs, have been carried out well by Local Government Clinic, including Local Government Clinic, which has prepared a system and SOP to provide services to mothers and children.

The referral system aspect has not been done well by the Local Government Clinic, which is indicated by the average value of the 3.3 research results.

The performance of policy implementation in the aspect of budgeting is still not optimal, among others, the cost of transportation of blood donors is borne by the government (average value of 2.9). 
The performance of policy implementation as an impact on public health indicators can be seen in several achievements such as: Maternal Mortality Rate (MMR) 159/100,000 KH from the national target 102/100,000 KH. Coverage of infant mortality rate (IMR) 32/1000 KH from the national target 23/1000 KH. Labor in health facilities is $86 \%$, while the national target is $90 \%$. Labor is helped by health workers $86 \%$ while the national target is $96 \%$. K4 Coverage (Fourth pregnancy examination) $61.78 \%$ of the national target $85.85 \%$. Management of obstetric complications $46.5 \%$ of the national target of $73.3 \%$. Low Birth Weight (LBW) $15.5 \%$, the national target is $10.01 \%$. Achievement of neonatal treatment is $15.34 \%$ while national figure is $51.4 \%$. The achievement of the first neonatal visit (KN1) was $75.51 \%$ while the national target was $92.33 \%$. The service coverage for infants is $69.38 \%$ while the national target is $87.77 \%$. Immunization coverage is $80.69 \%$ while the national target is $100 \%$. The achievement of complete basic immunization (IDL) in infants was $68.90 \%$ while the national target was $89.86 \%$. Prevalence of Underweight Nutrition $33.0 \%$ while the national figure is $19.6 \%$. Below-normal height presentation is $51.7 \%$ while national figure is $37.2 \%$.

Some of the indicators above illustrate the impact of the implementation of MCH policies in East Nusa Tenggara Province. Almost all indicators have increased but are still less than the national target figure. It cannot be denied that the achievements of several health indicators are still very low compared to national figures and also with other provinces in Indonesia. Therefore, it is still necessary to optimize the role of various components of society and across sectors.

\subsection{Effect of Accessibility on MCH Policy Performance in East Nusa Tenggara Province}

The geographical conditions of East Nusa Tenggara which consists of oceans and mountains may have accessibility in island areas which are very difficult to reach by policy implementers and require considerable costs. Distribution of regions consisting of islands both large and small will affect the performance of policy implementation.

Table 3. Accessibility conditions based on MCH Policy Performance in East Nusa Tenggara Province in 2017

\begin{tabular}{|c|c|c|c|c|c|c|}
\hline & & \multicolumn{4}{|c|}{ Performance of Policy Implementation } & \multirow{2}{*}{ - Total } \\
\hline & & Not Good & Pretty good & Good & Very Good & \\
\hline \multirow{5}{*}{ Accessibility conditions } & Very not easy & 1 & 12 & 4 & 1 & 18 \\
\hline & Not easy & 17 & 43 & 24 & 2 & 86 \\
\hline & Quite easy & 2 & 35 & 39 & 3 & 79 \\
\hline & Easy & 2 & 5 & 37 & 3 & 47 \\
\hline & Very easy & 0 & 0 & 1 & 4 & 5 \\
\hline Total & & 22 & 95 & 105 & 13 & 235 \\
\hline
\end{tabular}

(Source: Primary Data, 2017).

Table 3 illustrates the performance of policy implementation categories both in harmony with the conditions of category accessibility quite easily and easily. However, the performance of the policy category is not well aligned with the conditions of accessibility with a bad category. The performance of $\mathrm{MCH}$ policy implementation with categories is quite good in line with the conditions of accessibility with categories that are not easy. To see the relationship between the conditions of accessibility and the performance of the implementation of $\mathrm{MCH}$ policies statistical tests were conducted as in the following table. 
Table 4. Relationship between Accessibility Conditions and the performance of $\mathrm{MCH}$ policies in East Nusa Tenggara Province in 2017

\begin{tabular}{|c|c|c|c|c|}
\hline & & & $\begin{array}{l}\text { Kinerja Implementasi } \\
\text { Kebijakan }\end{array}$ & $\begin{array}{l}\text { Kondisi } \\
\text { Aksesibilitas }\end{array}$ \\
\hline \multirow{6}{*}{$\begin{array}{l}\text { Spearman's } \\
\text { rho }\end{array}$} & \multirow{3}{*}{$\begin{array}{l}\text { Performance of Policy } \\
\text { Implementation }\end{array}$} & $\begin{array}{l}\text { Correlation } \\
\text { Coefficient }\end{array}$ & 1.000 & $.429^{* *}$ \\
\hline & & Sig. (2-tailed) & . & .000 \\
\hline & & $\mathrm{N}$ & 235 & 235 \\
\hline & \multirow{3}{*}{ Accessibility conditions } & $\begin{array}{l}\text { Correlation } \\
\text { Coefficient }\end{array}$ & $.429^{* *}$ & 1.000 \\
\hline & & Sig. (2-tailed) & .000 & . \\
\hline & & $\mathrm{N}$ & 235 & 235 \\
\hline
\end{tabular}

**. Correlation is significant at the 0.01 level (2-tailed).

Table 4 shows there is a correlation between accessibility and the performance of MCH policy implementation (p $=0.00$ ), the correlation coefficient of 0.429 shows that this correlation is quite strong, although not very strong. This means that the easier the condition of accessibility will improve the performance of MCH policy implementation. The results of partial linear regression test ( $t$ test), found $t$ count $=19.0115>t$ table 1.97 means that $\mathrm{Ho}$ is rejected or there is a significant influence on the condition of accessibility to the performance of KI policies in East Nusa Tenggara Province.

The effect of accessibility with policy performance is 0.141 , this means that every increase in one unit of accessibility factor will have an effect on the increase in the policy performance coefficient carried out at 0.141 times. Accessibility factors are fundamental because of the fact that the people of East Nusa Tenggara are spread over a wide area and are spread across islands throughout East Nusa Tenggara. People who live scattered on the islands are still partly living in groups with a simple lifestyle and traditional views. Most living in remote areas pay less attention to the importance of health and education. The community has not received health services evenly. This problem is not because the community does not want to, but because of the location of their residence which is not possible to reach health facilities. Such areas often do not allow for good health services. Besides accessibility factors, it is also an effort to instill an understanding of the importance of health because of a traditional lifestyle. Efforts made by the government are to bring health services closer to the community by building health facilities and increasing transportation facilities to the interior and islands.

The complexity of policy implementation is not only indicated by the number of actors or units involved, but also because the implementation process is influenced by various complex variables, both individual variables and organizational variables and each variable influences each other (Subarsono, 2013: 89).

The success of a policy or program is also assessed based on the perspective of the implementation process and results perspective. In a process perspective, government programs are said to be successful if their implementation is in accordance with the guidelines and implementation provisions made by program makers which include, among other things, how to implement, implementing agents, target groups and program benefits. Whereas in the results perspective, the program can be considered successful when the program has the desired effect. A program may be successful from the point of view of the process, but it may fail in terms of the resulting impact, or vice versa. This is in line with the statement of Mitchell F. Rice and William Verner JR (2016) that the success of implementing this policy can be attributed to a number of variables in the policy implementation process.

The results showed that there was an influence of accessibility variable (x) with policy performance variable (y) of 0.141 which indicates that every increase in one accessibility factor unit that supports the implementation of $\mathrm{MCH}$ service policy performance would have an effect on the increase in policy performance coefficient of 0.141 times more large compared to the influence given other factors.

According to Jones (1995: 33), to measure the performance or effectiveness of an organization three approaches can be used, namely: "External resource approach, technical approach, internal systems approach". External 
resource approach, namely measurement based on the ability of resources owned and managed by the organization to achieve performance or effectiveness. Then technical approach, namely measurement based on technological capabilities applied by the organization to achieve performance or effectiveness. Internal systems approach, which is a measurement based on the ability of an organization to develop and create something new (innovation) to respond quickly to changes in the environment.

Another opinion expressed by Edwards III (1980: 10-11) that, the performance or work effectiveness achieved by implementing organizations in the implementation of public policies will be determined by bureaucratic structure, resources, dispositions, communication factors.

Institutional performance relates to how far an institution has carried out all the main activities so as to achieve the institution's vision and mission. Performance (performance) is a description of the level of achievement of the implementation of an activity/program/policy in realizing the goals, objectives, vision, and mission of the organization which is usually contained in the strategic planning of an organization. The term performance is often used to refer to the achievement or level of success of individuals or groups of individuals.

Performance can be known only if the individual or group of individuals has established success criteria. These success criteria are in the form of specific goals or targets to be achieved. Without a goal or target, the performance of a person or organization cannot be known because there are no benchmarks. While performance measurement is a process of evaluating the progress of work towards predetermined standards and objectives, such as the efficient use of resources in producing goods and services, the quality of goods and services, the results of activities compared to the intended purpose, and effectiveness in achieving goals (Robertson in Mahsun, 2008: 25).

According to Lohman (2003) performance measurement is an activity of evaluating the achievement of certain targets derived from organizational strategy goals (in Mahsun, 2008: 25). Performance measurement is a management tool used to improve the quality of decision making and accountability and assist managers in monitoring implementation by comparing actual results with strategic goals and objectives. So performance measurement is a method or tool used to record and assess the achievement of implementation based on goals, objectives, and strategies so that the progress of the organization can be known as well as improving the quality of decision makers and accountability.

Performance measurement is not the end goal, but rather a tool to produce more efficient management and performance improvement. The results of performance measurements will describe what has been done. An organization must use performance measurement effectively in order to identify what strategies and operational changes are needed as well as the processes needed in these changes.

Health service performance is one of the important factors in efforts to improve the quality of health of the population. The low performance of health services can be seen from several indicators such as labor assistance by health workers, the proportion of infants who get measles immunization and the proportion of case detection (case detection rate) (Adisasmito, 2014:25).

\subsection{Research's Ethic}

The research data was taken after obtaining approval from the provincial government. The researcher proceeded to give brief explanation to the respondents about the study and asked for their individual consent. The respondents were free to withdraw from the study at any time and they were not required to answer questions which made them comfortable. Those who were willing to be participant signed on the informed consent and answered the questions voluntarily. The respondent did not write their names on the questionnaires to maintain anonymity. The data taken was being safely kept by lock and key.

\subsection{Appreciation}

The deepest gratitude expressed to The Governor of East Nusa Tenggara and The Director of Health Polytechnic of Health Ministry Kupang. Appreciation also given to the head of 11 districts of East Nusa Tenggara Province, The head of 104 Health Community Centers and 235 health workers who were willing to participate on this study.

\section{Conclusion}

1) The Conditions of accessibility and networking in maternal and child health services in East Nusa Tenggara Province still do not support the implementation of $\mathrm{MCH}$ policies.

2) The performance of the implementation of $\mathrm{MCH}$ policies in East Nusa Tenggara Province is in the category of 3.36, meaning that the targets of $\mathrm{MCH}$ services that have been made have not been maximally realized.

3) There is a strong and positive correlation between accessibility conditions and implementation performance. 


\section{Recommendation}

1) The government is expected to be more serious in efforts to open the accessibility of health services.

2) The government needs to set realistic targets to achieve the expected performance.

\section{Competing Interests Statement}

The authors declare that there are no competing or potential conflicts of interest.

\section{References}

Abdullah, A. D. (2015). Risk Factors for the death of Neonatal in East Nusa Tenggara Province: A Matched Case-Control Study. Kupang: AIPMNH.

Adisasmito, W. (2013). Academic Paper Design and Health Policy. Jakarta: UI-Press.

Adisasmito, W. (2014). Health System (2nd ed.). Depok: PT. Rajagrafindo Persada.

Agus, D. (2006). Creating Good Governance through Public Services. Yogyakarta: UGM Press.

Agustino, L. (2006). Fundamentals of Public Policy. Bandung: CV. Alfabeta.

Akhmad, Z. (2006). Policy Implementation of Family Planning Program in Batang Regency Case Study of Increasing the Participation of Male Family Planning in Gringsing Subdistrict (Thesis. Diponegoro University Postgraduate Program Study Program: Master of Administrative Sciences Concentration: Master of Public Administration).

Ali, I. (2013). Implementation of "Libas 2+" Health Policy as an Effort to Reduce Maternal and Infant Mortality in Sampang District. Indonesian Health Policy Journal, 2(3), 107-111.

Anderson, J. E. (2003). Public Policy Making: An Introduction (5th ed.). Boston: Houghton Mifflin Company.

Asmaripa, A., \& Misnaniarti. (2010). Implementation of the South Sumatra Health Social Security Policy in Palembang City Health Centers in 2009. Journal of Health Services Management, 13(2), 74-80.

Asna, A. (2010). Policy Implementation for the Urban Poverty Program (P2KP) in Gorontalo City. Journal of Public Administration, 1(1), Year 2010.

Azwar, S. (1995). Human Attitude: Theory and Measurement (2nd ed.). Yogyakarta: Student Library.

Buse, K., Mays, N., \& Walt, G. (2007). Making Health Policy, Making Health Policy. London: London School of Hygiene and Tropical Medicine.

Chairman of Commission V of the NTT DPRD, \& Wilson, R. (2015). Evaluation of the Implementation of the AIMNH Program, Snur Bali, Pos Kupang.Com 27/5/1015.

Chellys Zanky, T. L. (2011). Performance of the KIA Revolution Program (Maternal and Child Health) of the Regional Government of West Manggarai Regency, East Nusa Tenggara Province (Electronic Theses \& Dissertation (ETD). Gadjah Mada University).

Clarke, E. C., Lawrence, C. M., \& Carr, T. R. (2009). American Public Policy: An Introduction (9th ed.). Wadsworth Publishing.

Cochran, C. L., \& Eloise, F. M. (2005). Excerpted From Public Policy: Perspectives and Choices (3rd ed.). USA: Linny Rienner Publishers.

Dunn, W. N. (1994). Public Policy Analysis: An Introduction. New Jersey: Pearson Education (second edition Indonesian edition). Yogyakarta: Gadjah Mada University Press.

Dunn, W. N. (2000). Introduction to Public Policy Analysis (2nd ed.). Yogyakarta: Gadjah Mada University Press.

Dwiyanto, A. D. (2006). Public Bureaucracy Reform in Indonesia. Yogyakarta: Gadja Mada University Press.

East Nusa Tenggara Governor Regulation Number 42 Year 2009, Revolution of Mother and Child Health in East Nusa Tenggara Province.

East Nusa Tenggara Provincial Health Office. (2009). NTT Health Profile 2009. East Nusa Tenggara Provincial Health Office. Kupang.

East Nusa Tenggara Provincial Health Office. (2010). 2010 MCH Section Report. East Nusa Tenggara Provincial Health Office. Kupang.

East Nusa Tenggara Health Office. (2012). Guidelines for MCH (Maternal - Child Health) Rebounding. NTT health office. Kupang.

East Nusa Tenggara Provincial Government. (2014). NTT Province Regional Medium-Term Development Plan 
(RPJMD) for 2013-2018. Kupang: NTT Regional Government.

Edward III, G. C. (1984). Public Policy Implementing. London-England: Jai Press Inc

Frank, F., Miller, G. J., \& Sidney, M. (2007). Handbook of Public Policy Analysis Theory, Politics, And Methods. CRC Press Is An Imprint of The Taylor \& Francis Group, An Informa Business. https://doi.org/10.1201/9781420017007

Gae Dopo, A. (2013). Revoolusi Policy Analysis on Maternal and Child Health: On the Aspect of Human Resources Health in the Waepana Health Center, Soa District, Ngada District, NTT (Thesis, Satya Wacana Christian University).

Gerston, L. N. (2002). Public Policy Making in a Democratic Society: A Guide to Civic Engagement. Armonk: M. E. Sharpe.

Goggin, M. L. et al. (1990). Implementation, Theory and Practice: Toward a Third Generation. USA: Foresmann and Company.

Grindle, M. S. (1980). Politics and Policy Implementation in The Third World. New Jersey: Princnton University Press. https://doi.org/10.1515/9781400886081

Haedar, A. (2010). Policy Implementation: What, Why and How. Journal of Public Administration, 1(1), Yr.

Hamzah, B. U. (2007). Motivation Theory and Measurement, Analysis in the Field of Education. Jakarta: Earth Literacy.

Hardiman, F. B. (2010). Public Spaces, Track Democratic Participation from Policy to Cyberspace. Yogyakarta: Canisius Publishers.

Health Office. (2014). 2014 Maternal and Child Health Report. Seminar Material.

Health Office. (2015). Technical Guidelines for the Leap to Reducing Infant Death in NTT Province. Kupang: Health Office of NTT and AIPMNH.

Health Research and Development Agency. (2013). Basic Health Research (RISKESDAS 2013). Jakarta: Indonesian Ministry of Health.

Herman, S. (2008). Human Resource Management (1st ed.). Yogyakarta: Graha Science Publisher.

Irawan, P. (2007), Qualitative and Quantitative Research for the Social Sciences. Jakarta: Department of Science Ad.

Jehaman, Y. A. (2011). Analysis of sociodemographic factors and the use of Antenatal Care for newborn deaths in Kupang City in 2010. Faculty of Public Health Undana: Thesis. Kupang.

Jiarti, K., Martha, I. K., \& Sri, A. N. (2014). Analysis of Implementation of Class Program for Pregnant Women by Midwives Puskesmas in Malang City. Journal of Health Technology, 10(1), 50-55. https://doi.org/10.33475/jikmh.v2i1.94

Kay, A. (2006). The Dynamics of Public Policy Theory and Evidence (Department of Politics and Public Policy (Griffith University, Brisbane, Australia New Horizons in Public Policy Edward Elgar Cheltenham, UK Northampton, Ma, Usa).

Khozin, M. (2010). Evaluation of the Implementation of Minimum Pelyanan Standard Policies in Health in Gunung Kidul Regency. Journal of Government Science Studies, 1(1), August 2010. https://doi.org/10.18196/jgp.2010.0003

Laksono A. D, (2016). Accessibility of Health Services in Indonesia. Special Region of Yogyakarta: PUBLISHER OF PT KANISIUS.

Law number 36 of 2009, about Health.

Lince, M. (2011). The Significance of Community Participation in Public Policy in Regions: Analysis by David Easton's System Theory. Proceeding of the 2011 National Autonomy Regional Symposium Lab-Ane Fisip Untirta.

Lukman, A. (2008). Implementation of Perda Policy No. 7 of 1992 concerning IMB (Building Permit) in the City of Surabaya. Journal of Social Sciences, 8(2), 84-91.

Mardijanto, \& Mubasysyir, H. (2005). Evaluation of Integrated Management of Sick Toddler in Pekalongan District. JMPK, 8(1), March/2005.

Michael, H., \& Peter, H. (2002). Implementing Public Policy: Governance in The Middle in Practice. London: 
SAGE Publications.

Mohammad, K. (2010), Evaluation of Policy Implementation for Minimum Service Standards in the Health Sector in Gunungkidul Regency. Journal of Government Studies, 1(1). https://doi.org/10.18196/jgp.2010.0003

Mubasysyir, H. (2012). Maximization, Free Reder and Policy Implemetation Failure. Indonesian Health Policy Journal, 1(3), September 2012.

Mulyadi, D. (2015). Public Policy and Public Service Studies, Concepts and Applications of Public Policy Processes and Public Services. Bandung: Alphabet Publisher.

Nakamura, R. T., \& Frank, S. (1980). The Politics of Policy Implementation. New York: St. Martin Press.

Namsah, Y. (2011). Model of Basic Education Service Policy Implementation. Jakarta: Orbit Publishing Jakarta Publisher.

Nizwardi, A. (2013). Study on the Effectiveness of the Implementation of City Regulation Policies on Non-Smoking Zones (KTR) in Efforts to Reduce Active Smokers in West Sumatra in 2013. Indonesian Journal of Health Policy, 2(4), 171-179.

Nugroho, R. (2012). Public Policy for Developing Articles. Yogyakarta: Student Library Publisher.

Pamudji, S. (2004). State Administration Ecology. Jakarta: PT Bumi Aksara.

Parsons, W. (1995). Public Policy, an introduction to the theory and practice of policy analysis. Aldershot, UK; Brookfield, Vt., US: Edward Elgar.

Parsons, W. (2011). Public Policy, Introduction to Policy Theory and Practice Analysis. Jakarta: Kencana Prenada Media Group.

Provincial Government of East Nusa Tenggara. (2009). Governor Regulation No. 42 of 2009 concerning the MCH Revolution in NTT Province. Kupang: Provincial Health Office of NTT.

Peter, K., Corinne, L., Frédéric, V., \& Michael, H. (2007). PUBLIC POLICY ANALYSIS First Published In Great Britain In 2007. UK: Policy Press University of Bristol. https://doi.org/10.2307/j.ctt9qgz7q

Pratiwi, R., Chriswardani, S., Septo, P. A. (2012). Analysis of Formulation and Implementation of Regional Regulation Number 7 of 2008 concerning Early Breastfeeding and Exclusive Breastfeeding Initiatives in Klaten District, Proceedings of the National Seminar on Health Department of Public Health. FKIP- Unsoed, Purwokerto, 31 March 2012.

Priyatno, D. (2009). Independent Learning SPSS. Jakarta: PT. Our Book.

Purwanto, E. A., \& Dyah, R. S. (2012). Public policy implementation, concept and application in Indonesia. Yogyakarta: Gava Media Publisher.

Putro, G. (2013). Analysis of the Implementation of the Childbirth Guarantee Policy in Increasing Coverage of Health Workers at Situboondo in 2013. Journal of Indonesia Health Policy, 2(3), 112-117.

Rachmad, R., \& Hapsara, H. (2013). Accelerating Health Development in Indonesia. Yogyakarta: Gadjah Mada University Press.

Republic of Indonesia Ministry of Health (2013). Indonesia National Health Profile 2013. Jakarta: Ministry of Health Republic of Indonesia

Republic of Indonesia Ministry of Health. (2012). National Health System (SKN) in 2012. Jakarta: Ministry of Health Republic of Indonesia.

Republic of Indonesia Ministry of Health. (2013). Basic Health Research (RISKESDA) 2013. Jakarta: Ministry of Health Republic of Indonesia.

Republic of Indonesia Ministry of Health. (2015). National Medium-Term Development Plan (RPJMN) for 2015-20120. Jakarta: Ministry of Health Republic of Indonesia.

Republic of Indonesia Ministry of Health. (2015). Ministry of Health Strategic Plan for 2015-2019. Jakarta: Ministry of Health Republic of Indonesia.

Republic of Indonesia Ministry of Health. (2014). Indonesia Health Profile 2013. Jakarta: Ministry of Health Republic of Indonesia.

Republic of Indonesia Ministry of Health. (2013). Health Profile 2013. Jakarta: Ministry of Health Republic of Indonesia.

Riduan, K. M. (2007). Ecological Systems of Public Administration in Indonesia. Journal of Management \& 
Business Alliance, 2(3), May 2007. IMMI Jakarta.

Riggs, F. W. (1961). The Ecology of Public Administration. New Delhi: Asia Publishing House.

Rogers, E. M., \& Lawrence Kincaid, D. (1981). Communication Networks: Toward a New Paradigm for Research. New York: The Free Press.

Sabatier, P. A. (2007). Theories of the Policy Process. University of California: by Westview Press Published by Westview Press.

Sandra Fikawati, A. S. (2010). The Study on the Implementation and Policy of Exclusive Mother's Milk Nursing and Early Breastfeeding Initiations in Indonesia. Makara, Health, 14(1), 17-24.

Siagian, S. P. (1976). Administration and Development. Jakarta: Mount Agung.

Smith, K. B., \& Lincoln Christopher, W. L. (2009). The Public Policy Theory Primary. Westview Press, A Member of the Perseus Books Group.

Soedjiran, R. D. (1986). Introduction to ecology. Bandung: Remadja Karya.

Solekhan, M. (2014). Organization of Village Government Based on Community Participation. Malang East Java: Publisher Equivalent Press.

Subarsono (2005). Public Policy Analysis of Concepts, Theories and Applications. Yogyakarta: Student Library.

Sugiyono (2011). Administrative Research Methods. Bandung: Alphabet Publisher.

Sumarno, S. (2011). Optimization Model Implementation of Government Policies Regarding Warning of the Dangers of Smoking Against Cigarette (Smoker) Behavior and Social Costs. Riptek, 5(1), 19-29.

Supranto, J. (2008). Statistical Theory and Application (7th Ed.). Jakarta: Erlangga Publisher.

Syafiie, I. (2006). Public Administration. Jakarta: PT Rineka Cipta.

Tangkilisan, H. N. S. (2003). Theories and Concepts of Public Policy "in Grounded Public Policy, Concepts, Strategies and Cases. Yogyakarta: Lukman Offset and YPAPI, 2003.

Tashakkori Abbas and Charles Teddlie. (2010). Mixed Methodologoly, Combining Qualitative and Quantitative Approaches. Yogyakarta: Student Library Publisher.

Trumpet. (2014). Innovative Governance, Concepts and Applications. Yogyakarta: Capiya Publishing Publisher.

UNICEF. (2012). Malaria, Immunization and Integrated MCH. Kupang City NTT: Kairos Publisher.

United Nations Environment Program. (2009). Integrated Policymaking for Sustainable Development. Copyright United Nations Environment Program.

Wahab, S. A. (2014). Wisdom Analysis (2nd ed.). Jakarta: Earth Literacy Publisher.

Wibawa, S. (1994). Public policy. Jakarta: Intermedia

Wila, R. W., \& Mading, M. (2014). Determinants of Maternal and Child Health in West Manggarai Regency, East Nusa Tenggara Province, Research and Development Institute for Animal Sourced Diseases. West Sumba: P2B2 Waikabubak Workshop.

Winarno, B. (2002). What is Public Policy? "In Public Policy Theory and Process. Yogyakarta: Media Pressindo, 2002.

Yosef, L. M., Deni, K. S., \& Supriyati. (2013). National Policies in Local Contexts: Challenges in Implementing Desa Siaga Policies and Referral Health Services in Yapen Islands Regency, Papua. Indonesian Health Policy Journal, 2(1), 42-49.

Zulfian. (2014). Policy Implementation of Family Welfare Data Collection Program in the Distribution of Contraceptive Devices in Sintang Regency. Journal of Public Administration and Bureaucracy, 1(2), Article 4.

\section{Copyrights}

Copyright for this article is retained by the author(s), with first publication rights granted to the journal.

This is an open-access article distributed under the terms and conditions of the Creative Commons Attribution license (http://creativecommons.org/licenses/by/4.0/). 